\title{
Research on the Practice of College Grade Weekly Meeting Based on the Problem-Oriented
}

\author{
Yuxi $\mathrm{Niu}^{1, \mathrm{a}}$ \\ ${ }^{1}$ Student Affairs Office of School of Civil Engineering and Architecture, Wuhan University of Technology, Wuhan, China \\ a757004705@qq.com
}

\begin{abstract}
As the characteristic carrier and important way of school ideological and political work, grade weekly meeting plays an active role in college counselors to do a good job in students' safety and stability, build a harmonious campus and promote students' all-round development. However, the survey found that many grade weeks are just a formality and do not play a full role. The main reason is that they do not solve the practical problems of students from the perspective of students. Based on the problem-oriented thinking model, we innovate the teaching mode and content of grade weekly meeting based on the students' actual situation, so as to enhance students' sense of acquisition.
\end{abstract}

Keywords: problem-oriented, grade weekly meeting, counselors, mode

\section{INTRODUCTION}

College is an important milestone in the life of young students. Entering college campus at the time of adulthood is not only a successful transformation but also a brand new beginning for young students. It is also a key period for students' physical and mental health development and the formation and establishment of values. Colleges and universities shoulder the historical responsibility of training socialist builders and successors, and the mission of The Times is to help young students to fasten the "first button of life". Therefore, it is necessary to integrate the fundamental task of building morality into every aspect of young students' school life. General secretary xi jinping pointed out clearly at the national conference on ideological and political work in colleges and universities: "to improve students' ideological and political quality, we should guide them to have a correct understanding of the development trend of the world and China, to have a correct understanding of Chinese characteristics and international comparison, to have a correct understanding of the responsibilities and historical missions of The Times, to have a correct understanding of lofty aspirations and to be down-to-earth. [1]This puts forward higher requirements for colleges and universities to strengthen the ideal and belief education of college students and the education of successful success. The counselor is an important part of the teachers in colleges and universities, the backbone of moral education and ideological and political education for college students, and plays an important role in students' ideal and belief education and success education. [2]

\section{Responsibilities of College Counselors}

\subsection{Counselors are the Backbone of College Students' Ideal and Belief Education}

General secretary xi jinping has repeatedly stressed that young people must be firm in their ideals and beliefs.
Without ideals and beliefs, they will lack "calcium" in their spirit. Young college students are in the formation of values, in the face of the complex international situation, as well as the great challenges of the information age, to carry out ideal and belief education, to help young students establish correct values has become an important topic in colleges and universities. College counselors, as the backbone of college students' ideal and belief education, need to understand and master students' ideological trends, carry out targeted ideal and belief education, and educate and guide young college students to achieve four self-confidence.

\subsection{Counselors are the Organizers and Implementers of Daily Management of College Students}

The nature of counselors' work determines that counselors are the organizers and implementers of students' study and life in school. According to the regulations on the team construction of counselors in ordinary colleges and universities, counselors must take care of students and serve students around students. The job responsibilities of counselors require counselors to go deep into all aspects of students' study and life, such as ideological and political education, party and group construction, study style construction, mental health, career planning and employment guidance

\subsection{Counselors are Life Mentors and Bosom Friends for College Students to Grow into Talents}

Since the 18th National Congress of the Communist Party of China (CPC), China has made great progress and come closer to the goal of the great renewal of the Chinese nation than at any time in history. In order to realize the great Chinese dream, we need to pay attention to the development of higher education, pay attention to the quality of college talent training. The growth of young students requires all the 
efforts of universities. As a mentor and bosom friend, counselors play an important role in cultivating talents.

\section{THE SIGNIFICANCE AND CURRENT SITUATION OF GRADE WEEKLY MEETING}

grade weekly meeting is actually around the basic task of khalid ents, according to the characteristics of the college students' physical and mental development and need to grow up and in a particular core value system as the core, grade weeks as the carrier, and college students as the main participant in the educatees and to carry out a series of ideological and political education activities, to stimulate the students' inner yearning, so as to realize the freedom of college students' all-round development.[3]

\subsection{Explain the Situation and Policies, and Guide the Students to Achieve Four Self-confidence}

Faced with the current complex international and domestic forms, as well as the impact of the wave of big data, young students are faced with a large amount of information every day. Young students are in the forming period of value concept, and have not yet fully discerned consciousness and ability, so they are easy to be misled by some malicious and false information, thus affecting their own value concept. Use the platform of the annual conference to explain the forms at home and abroad, guide young people to be "confident in theory, system, road and culture", consciously resist the induction of bad information, and form their own correct values.

\subsection{Carried out the Relevant Work of the School and Performed the Responsibilities of the Counselor}

Grade weekly meeting system of grade provides an effective position and place for counselors to carry out their work and perform their duties. It can focus on the effective communication of school spirit and work, so that students can understand and get familiar with school life. Teachers, preach and teach to answer questions. Use the weekly meeting of grade to shorten the distance with students, answer students' questions in their study, life and career, timely deal with the difficult problems of students, and give full play to the work function of the counselor as the organizer and executor of daily management of college students.

However, in the process of investigation, it was found that some grade weekly meetings were mere formality, simply completing the functions of roll call and arranging work, without really giving full play to the role of grade weekly meetings. The attitude of students towards the weekly meeting of grade is indifferent and they think it is a waste of time, which is far from their expectation of the weekly meeting of grade. Therefore, many students choose to escape the weekly meeting of grade or deal with it negatively by playing mobile phones, which can't play the functions that the weekly meeting of grade should have. Therefore, facing the characteristics of college students' education management in the new era, it is necessary to innovate the implementation mode of the grade weekly meeting system, insist on the students' main body, take the question as the guidance, innovate in the content, method and mechanism of the grade weekly meeting, and enhance the effectiveness of counselors' guidance of students' value and the education of success.

\section{BASED ON THE PROBLEM - ORIENTED, INNOVATION GRADE WEEKLY MEETING MODEL}

\subsection{Highlight the Dominant Position of Students and Understand their Needs}

Grade weekly meeting is just a formality, the most important reason is not fully highlight the main status of students. As the guider and guide of the young students, the counselor plays an important role in the process of carrying out the fundamental task of building moral education. Young students are not only in the forming period of life value, but also in the key period of psychological quality. As the supply-side of the supply-demand relationship, counselors need to fully respect students' dominant position, fully understand students' ideological status and physical and mental development needs, think what students think, be anxious about what students need, and carry out targeted counseling. [4]The main body of the grade weekly meeting is students, and the theme of the weekly meeting should also focus on the actual needs of students. The counseling content of the weekly meeting should be close to the life of students, and solve their problems in a way that students can easily accept, By telling stories around them, carrying out practical activities, special case analysis and other ways, students can answer questions in their study and life, rather than simply reading and explaining policies. We should pay attention to changing roles and be a good teacher as well as a good friend. We should strengthen daily communication with students. At the same time, we should try to look at problems from the perspective of students and think about problems in the form of questions or questionnaires.

\subsection{Grasp the Law of Student Growth, Stratified Classification Guidance}

There is a substantial difference between college life and high school life. Students not only acquire knowledge from books, but also try to contact the society and transform theoretical knowledge into their professional ability. College students of different grades have different growth stages and environments, and different needs for growth. Therefore, it is particularly important to accurately grasp the law of students growth. According to the students of different grades, we should combine the needs of students' growth and carry out targeted stratification and classification guidance. As the transition period from senior high school to university, 


\section{REFERENCES}

It mainly lies in the formation of basic knowledge. Sophomore and junior years are the key stage for the training of professional knowledge and ability. Therefore, more guidance is needed from the perspective of life career planning. In junior and senior high school, the students will face looking for a job and graduate school choice, this time the students care about more problems, personal development is simple task arrangement clearly unable to meet the needs of students, so we need according to the different planning direction of students, targeted classification guidance, to solve the students growing confusion, help students to make choices. Through this form of hierarchical and classified guidance, students' urgent needs can be met, and the most practical and effective guidance and help can be provided for students at different growth stages.

\subsection{Respect the Development Law of the Times and Innovate Teaching Mode}

In the era of information explosion, students have more access to information and face a large amount of information to be processed every day. How to seize the highland of information field effectively, help students to get positive information in time and effectively, and strengthen the guidance of students' ideology has become a subject worthy of research in counselors' work. As an important position for counselors to lead the ideological value, grade week should also combine with the development rules of The Times, innovate teaching mode, and build a weekly meeting class that keeps pace with The Times and interests students. First, make use of new media to build an online platform for ideological and political education. Encourage and guide students to pay attention to international and domestic situations through forwarding or writing online articles, and adhere to the "four self-confidence". Second, innovate the presentation mode of grade week meeting, attract students' attention with the help of current affairs, hot news, video and education video, and improve the effectiveness of the week meeting. Grade third, innovation week activity form, the traditional grade weeks will typically counselors, students listen to, but that it is difficult to arouse the enthusiasm of students, can exert the principal role of students, the students involved in planning the weeks, say goodbye to the single form of teaching, take the debate, such as student thear students more interested in the activities of the form.

\section{CONCLUSION}

Based on the confusion and problems in the growing process of students, through the discussion of a series of innovative models and from the perspective of solving students' practical problems, knowledge publicity and guidance can successfully attract students' attention, guide students to externalize in practice and internalize in mind, and play the role of the weekly meeting of grade.
[1] Zhao Chen, Le Gao. Brief analysis on the use of cultural carrier in college students' ideological and political education [J]. Youth. 2017(23).

[2] Yang Zhe. Analysis of career identity of college counselors [J]. Contemporary tourism, 2018(01).

[3] Si Wenchao. Brief analysis on the connotation and function of subject education for college students [J]. Journal of Inner Mongolia Normal University (Educational Science), 2014(07):56-57.

[4] Du Qianju. Reflections on the work of college counselors [J]. Continue Education Research, 2006(05):96-98. 